Çukurova Üniversitesi Mühendislik Fakültesi Dergisi, 36(4), ss. 861-868, Aralık 2021

Cukurova University Journal of the Faculty of Engineering, 36(4), pp. 861-868, December 2021

\title{
Hayvansal Lif Karışımlı Kumaşların Isıl Tuşesi Üzerine Bir Araştırma
}

\section{Seval UYANIK ${ }^{* 1}$ ORCID $0000-0002-9513-5746$}

\author{
${ }^{1}$ Adlyaman Üniversitesi, Mühendislik Fakültesi, Tekstil Mühendisliği Bölümü, Adıyaman
}

Geliş tarihi: 03.08.2021～Kabul tarihi: 10.12.2021

Atıf şekli/ How to cite: UYANIK, S., (2021). Hayvansal Lif Karışımlı Kumaşların Isıl Tuşesi Üzerine Bir Araştırma. Çukurova Üniversitesi, Mühendislik Fakültesi Dergisi, 36(4), 861-868.

\section{$\ddot{\mathbf{O} z}$}

Tekstil sektöründe çevreye duyarlı ürünlere talebin artması doğal liflere ve dolayısıyla hayvansal liflere olan ilgiyi artırmıştır. Ancak hayvansal lifler ihtiyacı karşılama oranlarının düşük olması sebebiyle oldukça pahalı olup tekstil sektöründe genellikle düşük oranlarda diğer liflerle karışım halde kullanılmaktadır. Giysi konforu, son yıllarda oldukça önemli bir kavram haline gelmiş ve konforu yüksek giysiler çok daha fazla tercih edilmeye başlanmıştır. Kumaşların ısıl davranış özelliklerinin, giysi konforunu etkilediği bilinmektedir. Bu çalışmada hayvansal lif içeren kumaşların 1sıl soğurganlık özelliklerinin yani dokunma yolu ile kullanıcıya verdiği sıcak veya soğuk hissini ifade eden isıl tuşesinin ortaya koyulması amaçlanmıştır. Çalışma sonuçları kumaşlarda ısıl soğurganlığın; 1sıl iletkenlik, lif cinsi ve sıklık, gramaj, kalınlık gibi kumaş yapı parametrelerinden etkilendiğini ortaya koymuştur.

Anahtar Kelimeler: Hayvansal lif, Viskon lifi, Giysi konforu, Isıl soğurganlık (termal efüzyon), Kumaş yap1 parametreleri

\section{A Research on Thermal Effusivity of Blend Fabrics with Animal Fibers}

\begin{abstract}
The increase in the demand for environmentally friendly products in the textile sector has enhanced the interest in natural fibers and therefore animal fibers. However, animal fibers are quite expensive due to their low rate of meeting the needs, and they are generally used in low ratios in the textile industry as a mixture with other fibers. Clothing comfort has become a very important concept in recent years and clothes with high comfort have begun to be preferred more and more. It is known that thermal behavior properties of fabrics affect clothing comfort. In this study, it is aimed to reveal the thermal absorptivity (thermal effusivity) properties of fabrics containing animal fiber, that is, the thermal touch, which expresses the warm or cold feeling it gives to the user by touch. The results of the study showed that the thermal effusivity of the fabrics is affected by thermal conductivity, fiber type and fabric structure parameters such as density, weight, and thickness.
\end{abstract}

Keywords: Animal fibers, Viscose fiber, Clothing comfort, Thermal absorptivity (thermal effusivity), Fabric structure parameters

"Sorumlu (Corresponding author) yazar: Seval UYANIK, suyanik@adiyaman.edu.tr 


\section{GíRiș}

Tekstil sektörü kullanılan lifler açısından son derece zengin olup bitkisel ve hayvansal içerikli doğal lifler ile rejenere veya sentez yoluyla elde edilen yapay lifler olmak üzere birçok lif çeşidi bulunmaktadır.

Son yıllarda çevreye duyarlı ürünlere talebin artması doğal liflere olan ilgiyi artırmıştır. Ancak doğal liflerin kullanım oranı üretim kapasiteleriyle sınırlıdır ve bitkisel liflerle kıyaslandığında hayvansal liflerin ihtiyacı karşılama oranları oldukça düşüktür. $\mathrm{Bu}$ nedenle hayvansal lifler oldukça pahalı olup lüks lifler sınıfına girmektedir. Tekstil sektöründe de genellikle düşük oranlarda diğer liflerle karışım halde kullanımları yaygındır.

Hayvansal liflerin temel yap1 taşı protein olup hafiflik, yumuşak tuşe, sicak tutma, kolay ütülenebilirlik gibi olumlu özellikleri nedeniyle tercih edilirler [1].

Belli başlı hayvansal lifler; yün, ipek, tiftik kaşmir, angora ve deve soyu lifleri olup bunlardan ipek lifi salg1 kökenli iken diğerleri deride meydana gelen liflerdir.

Giysi konforu, son y1llarda oldukça önemli bir kavram haline gelmiş ve konforu yüksek giysiler çok daha fazla tercih edilmeye başlanmıștır.

Araştırmacılar tarafından giysi konforunun; vücudun termal dengesi ile yakından ilgili olduğu ve lif-iplik özellikleri, kumaş yapı parametreleri ve terbiye işlemlerinin 1 sıl konfor özelliklerini etkileyen faktörler olduğu belirtilmiştir [2-11].

Hayvansal liflerin en önemli özelliklerinden 1S1 tutma yeteneği, 1sıl özellik olduğu için giysi konforu ile doğrudan ilişkilidir.

Üte ve arkadaşları [12] çalışmalarında doğal renkli pamuk ile angora tavşanı lifini karıştırarak elde ettikleri ipliklerle bir yüzü \%100 renkli pamuk olan diğer yüzü ise doğal renkli pamuk/angora karışımlı çift yüzlü örme kumaşlar üretmişlerdir. Elde edilen ipliklerde tüylülük ve mukavemetin arttığını, düzgünsüzlüğün azaldığını, diğer yandan üretilen kumaşlarda angora oranının artmasıyla su buharı geçirgenliğinin düştüğünü ve ancak yüksek 1sıl özellikleri nedeniyle angora oranı yüksek karışım ipliklerin tercih edilebileceğini belirtmişlerdir.

Üte ve arkadaşları [13] bir diğer çalışmalarında, farklı karışım oranlarında yün/pamuk ve ipek/pamuk karışımlı ipliklerden üretilmiş süprem örme kumaşların iç giysilik olarak kullanımını konfor özellikleri açısından araştırmışlardır. Çalışma sonucunda, kumaşlarda yün lif oranı arttıkça yalıtım özelliklerinin iyileștiğini, ipek karışımlı kumaşların ise yüksek su buharı geçirgenliği, 1 sıl soğurganlık ve su emicilik özellikleri ile terlemenin yoğun olarak ortaya çıktığı yoğun aktivite koşulları için uygun olduğunu ortaya koymuşlardır.

Oğlakçığlu ve arkadaşları [14] tarafindan yapılan çalışmada, ring ve open-end iplik eğirme sistemleriyle üretilmiş pamuk/angora karışımlı iplikler örülerek elde edilen süprem kumaşların 1sıl konfor özellikleri incelenmiştir. Çalışma sonuçları karışımdaki angora miktarının arttırılması ile 1sıl konfor özelliklerinin azaldığını, ring eğirme ile üretilen kumaşın tuşesinin ve isı yalıtımının openend eğirme ile üretilen kumaştan daha üstün olduğunu göstermiştir.

Mumcu ve arkadaşları [15] yaptıkları çalışma ile ring ve vortex eğirme sistemlerinde viskon lifi ile karışım halde yün ve kaşmir liflerini farklı oranlarda kullanmak suretiyle $\mathrm{Ne} 30$ iplikler üretmiş ve bu ipliklerle üretilen kumaşların hava geçirgenliği ve boncuklanma direncini araştırmışlardır. Araştırma sonuçları; iplik eğirme sistemi, lif tipi ve karışım oranlarının kumaş performansı üzerine önemli oranda etki ettiğini ortaya koymuştur.

Malzemelerin 1s1l konfor özelliklerinin değerlendirilmesinde 1sıl iletkenlik ve 1 sil soğurganlık ölçümleri oldukça önemli yer tutmaktadır. Isıl iletkenlik $(\lambda)$, birim kalınlıkta malzemeden, 1 Kelvin sıcaklık farklılığında geçen 1s1 miktarı [9] iken 1sıl soğurganlık, malzemenin çevresi ile termal enerji alışverişi yapma yeteneğidir ve malzemelerin soğukluk veya 
sıcaklık hissini ifade eden yarı kalitatif ölçümdür [16] (Eşitlik 1).

Isıl soğurganlık $(e)=\sqrt{ }\left(\lambda \rho c_{p}\right)$

Formülde;

$\lambda$ - 1sil iletkenlik

$\rho$ - yoğunluk

$\mathrm{c}_{\mathrm{p}}$ - özgül 1sı kapasitesi

p.cp- hacimsel 1sı kapasitesi

Is1l efüzyon, kullanım amacına uygun olarak tekstil malzemelerinin seçimi ve kalitesi açısından dikkate alınması gereken ve nihai olarak ürün performansını etkileyen bir özellik olup düşük 1sıl efüzyona sahip malzemeler daha sicak, daha yüksek ısıl efüzyona sahip malzemeler daha soğuk hissedilir [17].

Çeşitli tekstil ürünlerinin efüzyon değerleri Şekil 1'de gösterilmiştir. Şekle göre 1sıl soğurganlık değeri $>200-280 \mathrm{Ws}^{1 / 2} / \mathrm{m}^{2} \mathrm{~K}$ olan malzemeler 'soğuk' hissi, efüzyon değeri $<65-100$ $\mathrm{Ws}^{1 / 2} / \mathrm{m}^{2} \mathrm{~K}$ olan malzemeler ise ' $11 \mathrm{k}$ ' hissi veren malzemeler olarak sınıflandırılmaktadır [17].

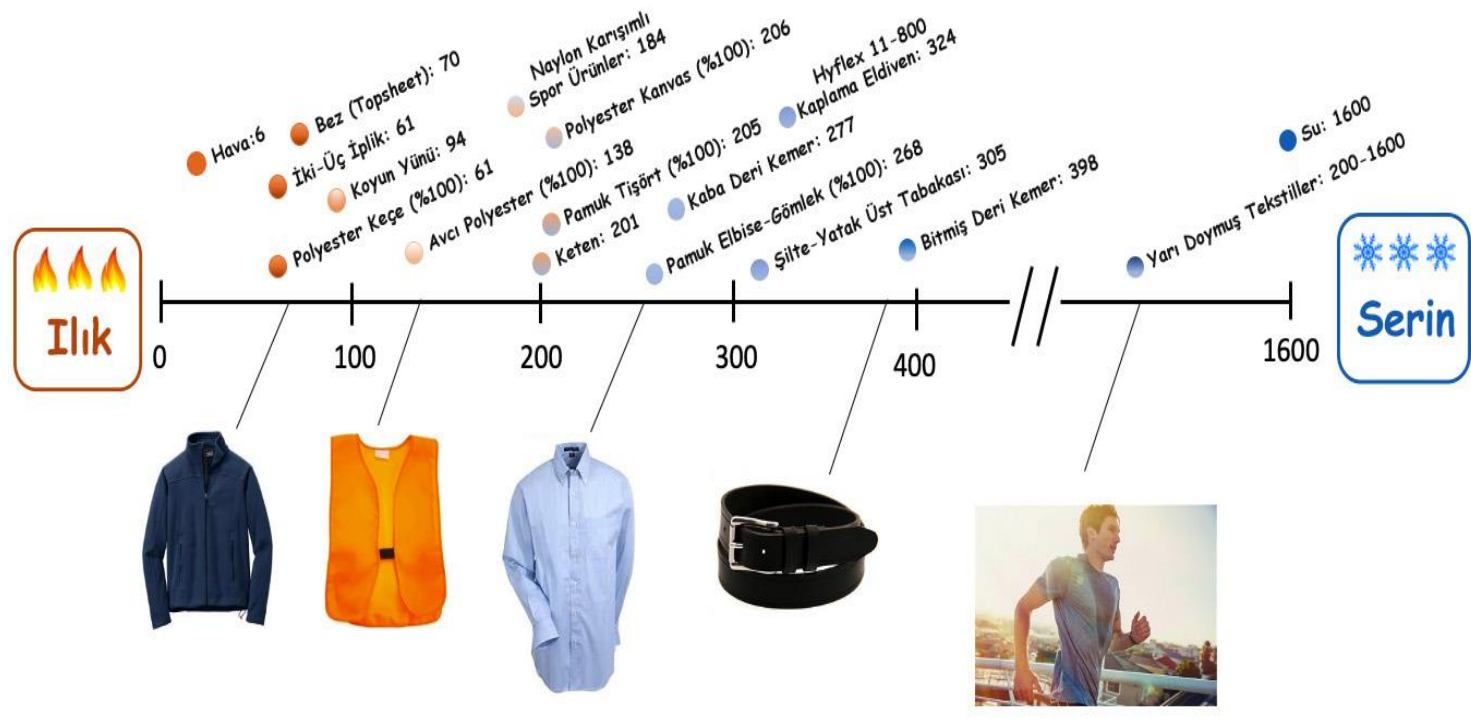

Isıl Soğurganlık (Termal Efüzyon) Birimi: W $\mathrm{s}^{1 / 2} / \mathrm{m}^{2} \mathrm{~K}$

Şekil 1. Çeşitli tekstil ürünlerinde 1sıl soğurganlık değerleri [17]

$\mathrm{Bu}$ çalışma kapsamında ise önceki çalışmalardan farklı olarak hayvansal lif içeren karışım ipliklerle örülen süprem kumaşlarda isıl iletkenlik ve efüzyon (soğurganlık) özellikleri, hayvansal lif içermeyen süprem kumaş ile karşılaştırmalı olarak incelenmiş ve hayvansal lif cinsi ve oranının belirtilen 1sıl özellikler üzerine etkilerinin belirlenmesi amaçlanmıştır.

Hayvansal lif içeren kumaşların 1sıl soğurganlık kapasitesinin yani dokunma yolu ile kullanıcıya verdiği sıcak veya soğuk hissini ifade eden isıl tuşe özelliğinin ortaya koyulması açısından mevcut çalışmanın literatüre katkı sağlayacağı ön görülmektedir.

\section{MATERYAL VE METOT}

Çalışma kapsamında ilk aşamada, ana lif olarak viskon $(\mathrm{CV})$ ile hayvansal lif bileşeni olarak yün (WO) ve kaşmir lifleri (WS) kullanılmak suretiyle farklı karışım oranlarında Ne 30 numara iplikler Murata Vortex (MVS) eğirme sisteminde üretilmiştir. Çizelge 1 'de elde edilen ipliklerin özellikleri verilmiştir. 
İkinci aşamada elde edilen iplikler Faycon CKM 01-S laboratuvar tipi, makine inceliği 18 iğne/inç (E18) olan yuvarlak örgü makinesinde örülmüştür. Örgü kumaşların yapısal özellikleri olan sıra- çubuk sıklıkları, gramaj ve kalınlık değerleri sırasıyla ilgili standartlara [18-20] göre belirlenmiş olup kumaş numunelerinin yapısal özellikleri Çizelge 2'de verilmiştir.

Çizelge 1. İplik özellikleri

\begin{tabular}{|l|c|c|c|c|c|c|c|}
\hline & $\begin{array}{c}\text { Düzgünsüzlük } \\
\mathbf{\%} \mathbf{C V}\end{array}$ & $\begin{array}{c}\text { İnce yer } \\
\mathbf{- 5 0 \%}\end{array}$ & $\begin{array}{c}\text { Kalın yer } \\
\mathbf{+ 5 0 \%}\end{array}$ & $\begin{array}{c}\text { Neps } \\
\mathbf{+ 2 0 0 \%}\end{array}$ & $\begin{array}{c}\text { Tüylülük } \\
\mathbf{H}\end{array}$ & $\begin{array}{c}\text { Uzama } \\
\mathbf{\%}\end{array}$ & $\begin{array}{c}\text { Mukavemet } \\
\mathbf{c N} / \text { tex }\end{array}$ \\
\hline$\% 100 \mathrm{CV}$ & 12,74 & 3,30 & 11,70 & 5,00 & 3,99 & 11,26 & 14,65 \\
\hline$\% 90 / 10 \mathrm{CV} / \mathrm{WO}$ & 13,91 & 20,00 & 25,60 & 38,10 & 4,37 & 9,10 & 12,01 \\
\hline$\% 80 / 20 \mathrm{CV} / \mathrm{WO}$ & 14,30 & 25,60 & 31,30 & 17,50 & 4,48 & 7,49 & 10,91 \\
\hline$\% 90 / 10 \mathrm{CV} / \mathrm{WS}$ & 13,52 & 14,40 & 11,30 & 10,00 & 4,33 & 9,00 & 12,18 \\
\hline$\% 80 / 20 \mathrm{CV} / \mathrm{WS}$ & 15,94 & 63,30 & 147,50 & 273,30 & 4,93 & 8,14 & 10,78 \\
\hline
\end{tabular}

Çizelge 2. Yapısal kumaş özellikleri

\begin{tabular}{|c|c|c|c|c|c|}
\hline Kumaş cinsi & $\begin{array}{c}\text { İlmek sıra } \\
\text { sayısı/cm (cpc) }\end{array}$ & $\begin{array}{c}\text { İlmek çubuk } \\
\text { sayısi/cm (wpc) }\end{array}$ & $\begin{array}{c}\text { İlmek yoğunluğu* } \\
\text { ilmek } / \mathrm{cm}^{2}\end{array}$ & $\begin{array}{c}\text { Gramaj } \\
\mathrm{g} / \mathrm{m}^{2}\end{array}$ & $\begin{array}{c}\text { Kalınlık } \\
\mathbf{m m}\end{array}$ \\
\hline$\% 100 \mathrm{CV}$ & 14,67 & 9,00 & 132,03 & 100,30 & 0,47 \\
\hline$\% 90 / 10 \mathrm{CV} / \mathrm{WO}$ & 16,50 & 9,00 & 148,50 & 107,13 & 0,48 \\
\hline$\% 80 / 20 \mathrm{CV} / \mathrm{WO}$ & 17,33 & 9,17 & 158,92 & 109,90 & 0,50 \\
\hline$\% 90 / 10 \mathrm{CV} / \mathrm{WS}$ & 16,10 & 9,00 & 144,90 & 101,92 & 0,53 \\
\hline$\% 80 / 20 \mathrm{CV} / \mathrm{WS}$ & 17,50 & 9,40 & 164,50 & 105,14 & 0,56 \\
\hline
\end{tabular}

(*İlmek yoğunluğu = cpc x wpc)

Elde edilen kumaşların 1sıl iletkenlik ve soğurganlık değerleri, C-Therm-TCI cihazı ile ASTM D7984-16 standardına göre [21] tespit edilmiştir. Her bir numune için 5'er ölçüm yapılmış ve sonuçların ortalama değerleri Çizelge 3'te verilmiştir.

Çalışma sonuçlarının istatistiksel olarak değerlendirilmesi amaciyla SPSS 21 paket programı yardımıyla \%95 güven aralığında ANOVA ve Pearson korelasyon testleri uygulanmıştır.

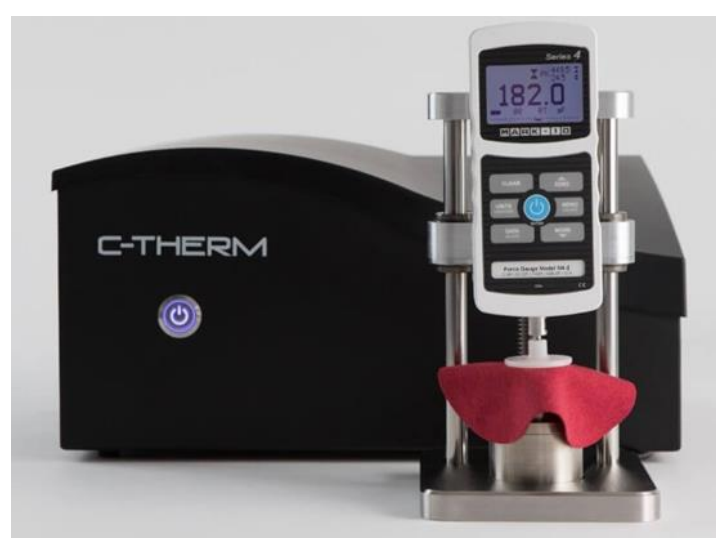

Şekil 2. C-Therm-TCI 1sıl iletkenlik-soğurganlık test cihaz1

Çizelge 3. Kumaşların ısıl soğurganlık ve iletkenlik sonuçları

\begin{tabular}{|l|c|c|c|c|c|}
\hline & $\begin{array}{c}\text { Isıl Soğurganlık } \\
\mathbf{W} \sqrt{ }(\mathbf{s}) / \mathbf{m}^{\mathbf{2}} \mathbf{K}\end{array}$ & $\begin{array}{c}\text { Isıl İletkenlik } \\
(\mathbf{W} / \mathbf{m K})\end{array}$ & $\begin{array}{c}\text { Ortam Sıcaklığı T } \\
\left({ }^{\circ} \mathbf{C}\right)\end{array}$ & $\begin{array}{c}\text { Delta T } \\
\left({ }^{\circ} \mathbf{C}\right)\end{array}$ & $\begin{array}{c}\text { V0 } \\
(\mathbf{m V})\end{array}$ \\
\hline$\% 100 \mathrm{CV}$ & 24 & 0,040 & 20,73 & 1,47 & $2.450,03$ \\
\hline$\% 90 / 10 \mathrm{CV} / \mathrm{WO}$ & 130 & 0,070 & 20,71 & 1,35 & $2.449,24$ \\
\hline$\% 80 / 20 \mathrm{CV} / \mathrm{WO}$ & 131 & 0,070 & 20,89 & 1,35 & $2.449,70$ \\
\hline$\% 90 / 10 \mathrm{CV} / \mathrm{WS}$ & 136 & 0,073 & 20,68 & 1,35 & $2.449,27$ \\
\hline$\% 80 / 20 \mathrm{CV} / \mathrm{WS}$ & 128 & 0,070 & 21,01 & 1,35 & $2.449,74$ \\
\hline
\end{tabular}




\section{BULGULAR VE TARTIŞMA}

Şekil 3'te verilen grafikten 1sıl iletkenlik sonuçları incelendiğinde; saf viskon kumaşın isıl iletkenlik değerinin hayvansal lif içeren kumaşlardan düşük olduğu, diğer hayvansal lif içeren kumaşların ise aynı iletkenlik değerine sahip iken sadece $\% 10$ kaşmir içeren kumaşın biraz daha yüksek iletkenliğe sahip olduğu görülmektedir.

Çizelge 4'te verilen ANOVA sonuçları $\left(\mathrm{p}_{\mathrm{wo}}=0,296 ; \mathrm{p}_{\mathrm{ws}}=0,126\right)$ hayvansal liflerin $1 \mathrm{~s} 1 \mathrm{l}$ iletkenlik üzerinde fark yaratmadığını gösterirken Çizelge 5'te verilen Pearson korelasyon sonuçları $\left(\mathrm{r}=-0,697^{* *}\right)$ viskon oranı ile 1s1l iletkenlik arasında ters yönlü ve kuvvetli bir ilişki olduğunu, viskonun artmasıyla iletkenlik değerinin azaldığını ortaya koymuştur.

Kumaş yapısal parametreleri açısından ANOVA sonuçları $(p=0,009)$ ilmek yoğunluğunun isıl iletkenlik üzerinde etkili olduğunu göstermiștir. Pearson korelasyon sonuçları $\left(r=0,561^{* *} ; r=0,479^{*}\right.$; $\mathrm{r}=0,431^{*}$ ) ilmek yoğunluğu, gramaj ve kalınlık parametreleri ile 1sil iletkenlik arasında pozitf yönlü ve orta kuvvetli ilişkilerin olduğunu ve bu parametrelerin değerlerinin artmasıyla iletkenlik değerinin de arttığını ifade etmektedir.

Numune kumaşların 1sıl soğurganlık değerlerini içeren Şekil 4'te verilen grafiğe göre \%100 viskon kumaş hayvansal lif içeren kumaşlardan çok daha düşük soğurganlık değerine sahipken $\% 10$ kaşmir lifi içeren kumaş diğer yün ve kaşmir liflerini içeren kumaşlardan biraz daha yüksek soğurganlık değerine sahiptir.

ANOVA sonuçlarına (Çizelge 4) göre viskon lifi $(\mathrm{p}=0,000)$ ile kumaş yapı parametrelerinden ilmek yoğunluğu $(p=0,011)$, gramaj $(p=0,002)$ ve kumaş yoğunluğu $(\mathrm{p}-0.002)$, 1sıl soğurganlık üzerinde etkili gözükmektedir.

Pearson korelasyon sonuçları da viskon lifi $\left(r=-0,719^{* * *}\right)$ ile 1sıl soğurganlık arasında kuvvetli ve ters yönlü bir ilişki olduğunu diğer taraftan ilmek yoğunluğu $\left(\mathrm{r}=0,564^{* *}\right)$, gramaj $\left(\mathrm{r}=0,513^{* *}\right)$ ve kalınlık $\left(r=0,433^{*}\right)$ ile 1 sıl soğurganlık arasında orta kuvvetli ve pozitif yönlü bir ilişki işaret etmektedir.

Malzemelerin 1sıl soğurganlığı, formül 1'de verilen eşitlikten görüldüğü üzere o malzemeye ait ${ }_{1 s} 1$ iletkenlik, yoğunluk ve özgül ısı değerleriyle doğru orantılıdır. Şekil 3 ve 4 incelendiğinde 1 s1l iletkenlik ve soğurganlık değerlerinin söz konusu ifadeyi destekler nitelikte olduğu ve iletkenlik arttıkça soğurganlığın da arttığı açıkça görülmektedir.

Özgül 1S1 değerlerinin pamuk lifinde $1,21 \mathrm{~J} / \mathrm{gK}$, rayon liflerinde (viskon, modal vb.) $1,26 \mathrm{~J} / \mathrm{gK}$, yün lifinde $1,36 \mathrm{~J} / \mathrm{gK}$ ve ipek lifinde $1,38 \mathrm{~J} / \mathrm{gK}$ olduğu bilinmektedir [3]. Buna göre hayvansal liflerin özgül 1sı değerlerinin selülozik liflerinkinden daha yüksek olmasının bir sonucu olarak hayvansal lif içeren numune kumaşlarda \%100 viskon kumaşa göre daha yüksek 1sıl soğurganlık değerleri gözlenmiştir.

Is1l soğurganlığı etkileyen diğer bir parametre olan kumaş yoğunluğu, kumaş yap1 özelliklerinin bileşimidir ve her bir yapısal özellik yoğunluğa ve dolayısıyla 1 sıl soğurganlığa tesir etmektedir. İstatistiksel değerlendirmeler de ilmek yoğunluğu, gramaj ve kalınlık gibi yapısal parametrelerin 1sıl soğurganlığı etkilediğini ortaya koymuştur. Böylece kumaşta yoğunluk artı̧ıına neden olan sıklık (ilmek yoğunluğu), gramaj ve kalınlık değerlerindeki artış çalışma sonuçlarında görüldüğü gibi 1 ssl $\quad$ soğurganlığın artmasını sağlamıştır.

Dokunsal his yani malzemeye el ile temasta verdiği sıcak veya soğuk hissinin bir ifadesi olan 1s1l soğurganlık; kumaşın gözeneklilik, yüzey yapısı, temas yüzeyi ile de bağıntılıdır [22]. Numune kumaşların 1sıl soğurganlık ölçüm sonuçlarına göre Şekil 1 incelendiğinde $\% 100$ viskon kumaşın en düşük değer ile hayvansal lif içeren viskon kumaşlara göre sıcak hissi verdiği diğer tüm kumaşların ise birbirine yakın değerler ile 1 lık hissi verdiği görülmektedir. Şekil 1 açısından değerlendirmede \%100 viskon kumaşın selülozik kökenli olması nedeniyle pamuk ve keten malzemelere yakın bir şekilde daha yüksek 1 sıl soğurganlık değerlerine sahip olması beklenirken 
çalışmada çok daha düşük değer gözlenmiştir. Bu durumun, $\% 100$ viskon kumaşın ilmek yoğunluğunun çok düşük olması ve bunun sonucu olarak gözenek yoğunluğunun yüksek olmasından kaynaklandığı düşünülmektedir. Başka bir ifadeyle sıklığın düşük olması kumaş gözenekleri arasında hava varlığının daha fazla olmasını ve böylece isıl soğurganlık değeri çok düşük olan havanın
(6 W $\left.\mathrm{W}(\mathrm{s}) / \mathrm{m}^{2} \mathrm{~K}\right)$ bulunduğu viskon kumaşın soğurganlık değerini düşürdüğü anlaşılmaktadır. Hayvansal lifler açısından ise yün ve kaşmir lifleri içeren kumaşların 1sıl soğurganlık değerlerinin yakın olması, söz konusu liflerin 1sıl soğurganlık açısından birbirlerinden pek farklı olmadığını göstermiştir.

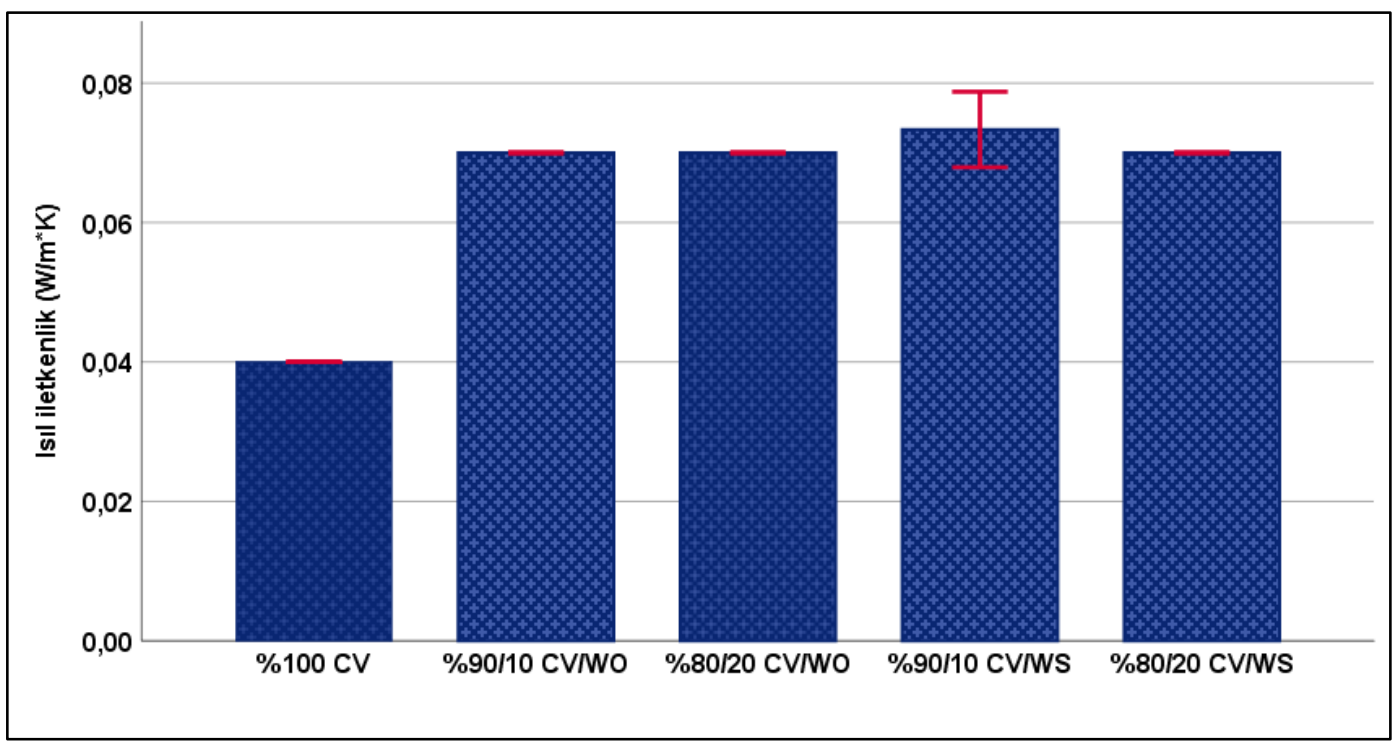

Şekil 3. Numune kumaşların 1sıl iletkenlik sonuçları

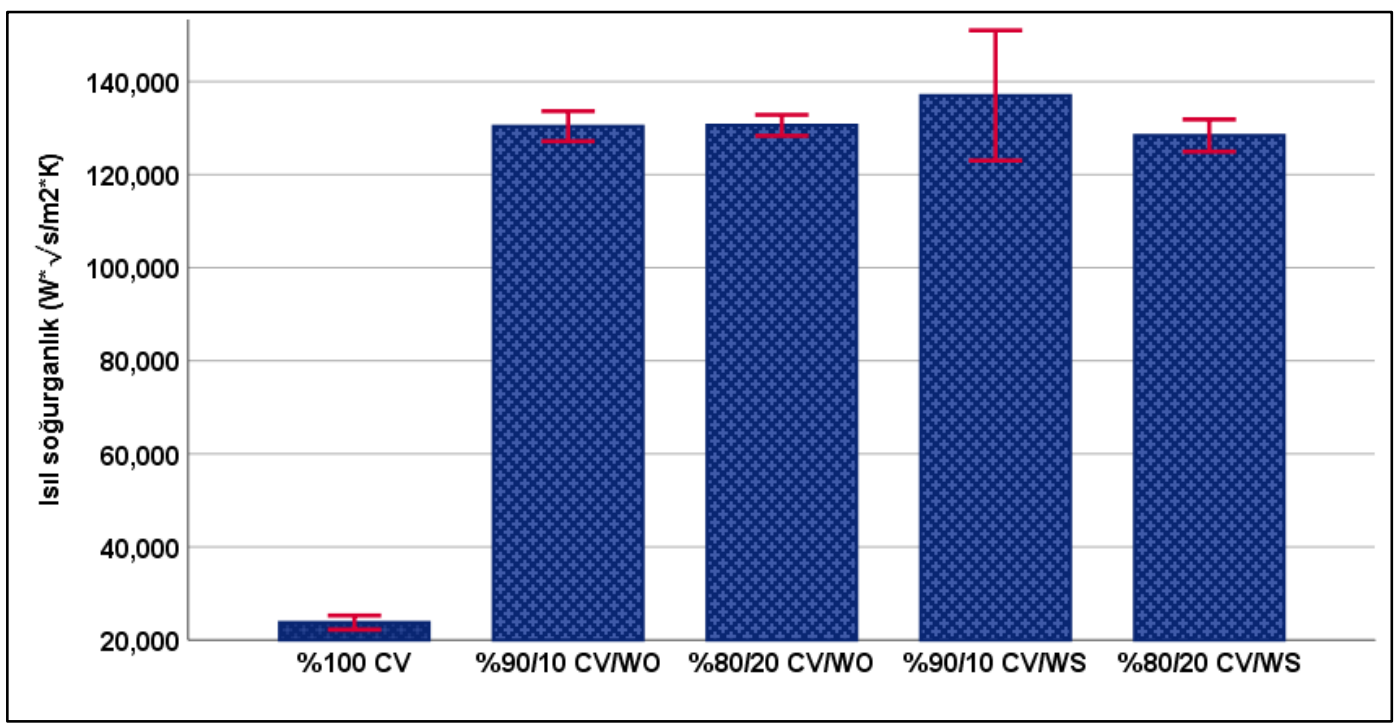

Şekil 4. Numune kumaşların 1sıl soğurganlık sonuçları 
Çizelge 4. ANOVA sonuçları

\begin{tabular}{|l|c|c|c|c|}
\hline \multirow{2}{*}{ Değişken } & \multicolumn{2}{|c|}{ Isıl İletkenlik } & \multicolumn{2}{c|}{ Isıl Soğurganlık } \\
\cline { 2 - 5 } & $\mathbf{F}$ & Anlamlılık & F & Anlamlılık \\
\hline CV & $\mathbf{2 1 7 , 5 5 6}$ & $\mathbf{0 , 0 0 0}$ & $\mathbf{3 9 6 , 1 8 0}$ & $\mathbf{0 , 0 0 0}$ \\
\hline WO & 0,936 & 0,407 & 1,286 & 0,296 \\
\hline WS & 2,827 & 0,081 & 2,280 & 0,126 \\
\hline İlmek yoğunluğu & $\mathbf{4 , 6 8 3}$ & $\mathbf{0 , 0 0 9}$ & $\mathbf{4 , 4 9 5}$ & $\mathbf{0 , 0 1 1}$ \\
\hline Gramaj & - & - & $\mathbf{4 3 2 , 7 2 4}$ & $\mathbf{0 , 0 0 2}$ \\
\hline Kalınlık & 1,217 & 0,369 & 1,354 & 0,304 \\
\hline Yoğunluk & - & - & $\mathbf{4 3 2 , 7 2 4}$ & $\mathbf{0 , 0 0 2}$ \\
\hline
\end{tabular}

Çizelge 5. Pearson korelasyon sonuçları

\begin{tabular}{|l|c|c|}
\hline Faktör & Isıl İletkenlik & Isll Soğurganlık \\
\hline CV & $-0,697^{* *}$ & $-0,719^{* * *}$ \\
\hline WO & 0,257 & 0,298 \\
\hline WS & 0,363 & 0,342 \\
\hline İlmek yoğunluğu & $0,561^{* *}$ & $0,564^{* *}$ \\
\hline Gramaj & $0,479^{*}$ & $0,513^{* *}$ \\
\hline Kalınlık & $0,431^{*}$ & $0,433^{*}$ \\
\hline Yoğunluk & $-0,188$ & $-0,176$ \\
\hline **. Korelasyon 0.01 düzeyinde anlamlıdır (2-yönlü). \\
*. Korelasyon 0.05 düzeyinde anlamlldır (2-yönlü).
\end{tabular}

\section{SONUÇLAR}

Çalışmada hayvansal lif içeren kumaşların termal efüzyon (1sıl soğurganlık) kapasitesinin yani dokunma yolu ile kullanıcıya verdiği sıcak veya soğuk hissini ifade eden 1sıl tuşe özelliğinin ortaya koyulması amaçlanmıştır.

Çalışma sonuçları kumaşlarda 1 sıl soğurganlığın (termal efüzyon) 1sıl iletkenlik, lif cinsi ve sıklık, gramaj, kalınlık gibi kumaş yapı parametrelerinden etkilendiğini kanıtlamıştır.

Özellikle kumaşta sıklığın veya gözenek yoğunluğunun bir ifadesi olan ilmek yoğunluğunun düşük olmas1 durumunda gözeneklerde artan hava yoğunluğunun etkisiyle daha düşük 1sıl soğurganlık ortaya çıkmıştır. Neticede düşük sıklığa sahip \%100 viskon kumaşın daha düşük isıl soğurganlık değeri ile hayvansal lif içeren viskon kumaşlara göre daha llı dokunma hissi verdiği, yün ve kaşmir lifleri arasında ise 1 sıl tuşe açısından fark olmadığı belirlenmiştir.

\section{TEŞEKKÜR}

Çalışma kapsamında iplik ve kumaş numunelerinin üretilmesini gerçekleştiren KARAFIBER HOLDİNG'e ve termal testlerin yapılmasinda destek veren Liberec Teknik Üniversitesi, Tekstil Mühendisliği Fakültesi'nden Ladislav Nagy'ye teşekkürlerimi sunarım.

\section{KAYNAKLAR}

1. Mengüç, S.G., 2012. Bazı Özel Hayvansal Liflerden Elde Edilen İpliklerden Üretilen Kumaşların Özellikleri Üzerine Bir Araştırma. İzmir, Bornova: Ege Üniversitesi Fen Bilimleri Enstitüsü, 312.

2. Li, Y., 2001. The Science of Clothing Comfort. Textile Progress, 31(1/2), 64-77.

3. Marmaral1, A., Dönmez Kretzschmar, S., Özdil, N., Gülsevin Oğlakçığlu, N., 2006. Giysilerde Isıl Konforu Etkileyen Parametreler. Tekstil ve Konfeksiyon, 16(4), 241-246.

4. Oglakcioglu, N., Marmarali, A., 2007. Thermal Comfort Properties of Some Knitted Structures, 
Fibres \& Textiles in Eastern Europe, 15(5-6), 64-65.

5. Öner, E., Okur, A., 2010. Materyal, Üretim Teknolojisi ve Kumaş Yapısının Termal Konfora Etkileri. Tekstil ve Mühendis, 17(80), 20-29.

6. Majumdar, A., Mukhopadhyay, S., Yadav, R., 2010. Thermal Properties of Knitted Fabrics Made from Cotton and Regenerated Bamboo Cellulosic Fibres. International Journal of Thermal Sciences, 49(10), 2042-2048.

7. Bilgi, M., Kalaoğlu, F., 2010. The Effects of Special Finishing Processes on the Performance and Comfort of the Military Garments. Tekstil ve Konfeksiyon, 20(4), 343-347.

8. Ertekin, G., Marmaralı, A., 2011. Yuvarlak Örme Sandviç Kumaşların Isı, Hava ve Su Buharı Transfer Özellikleri. Tekstil ve Konfeksiyon, 21(4), 369-373.

9. Sampath, M.B., Aruputharaj, A., Senthilkumar, M., Nalankilli, G., 2012. Analysis of Thermal Comfort Characteristics of Moisture Management Finished Knitted Fabrics Made from Different Yarns. Journal of Industrial Textiles, 42(1), 19-33.

10. Gorjanc, D.S., Dimitrovski, K., Bizjak, M., 2012. Thermal and Water Vapour Resistance of the Elastic and Conventional Cotton Fabrics. Textile Research Journal, 82(14), 1498-1506.

11. Uyanık, S., Kaynak, H.K., 2019. Pamuklu Elastan Süprem Kumaşlarda Konfor ve Boncuklanma Özellikleri. Çukurova Üniversitesi Mühendislik, Mimarlık Fakültesi Dergisi, 34(1), 13-22.

12. Üte, T.B., Oğlakçığlu, N., Çelik, P., Marmaralı, A., Kadoğlu, H., 2008. Doğal Renkli Pamuk/Angora Tavşan Lifi Karışımından Üretilen İpliklerin Özellikleri ve Örme Kumaşların Isıl Konforuna Etkileri Üzerine Bir Araştırma. Tekstil ve Konfeksiyon, 18(3), 191-196.

13. Üte, T.B., Çelik, P., Kadoğlu, H., Üzümcü, M.B., Ertekin, G., Marmaralı, A., 2018. Farklı Doğal Liflerin İç Giysilerde Kullanımının Konfor Özellikleri Açısından Araştırılması. Tekstil ve Mühendis, 25(112), 335-343.

14. Oglakcioglu, N., Celik, P., Ute, T.B., Marmarali, A., 2009. Thermal Comfort
Properties of Angora Rabbit/cotton Fiber Blended Knitted Fabrics. Textile Research Journal, 79(10), 888-894.

15. Mumcu, H.S., Çakır, G., Yayla, O., Gül, F., Tektunalı, S., Nohut, S., 2019. Hayvansal Lifler Kullanılarak Oluşturulan Kumaşların Performans Özelliklerinin İncelenmesi. Ulusal Çukurova Tekstil Kongresi-UÇTEK'2019 2627 Eylül 2019, Adana, TÜRKIYYE

16. https://tr.esc.wiki/wiki/Thermal_inertia, Erişim tarihi: 02.07.2021.

17. https://ctherm.com/products/tx-thermal-

effusivity-touch-tester/, Erişim tarihi: 12.08.2021.

18.TS EN 14971: 2013. Tekstil-Örülmüş Kumaşlar-Birim Uzunluk ve Birim Alan Başına Örgü İlmeği Sayısının Tayini.

19. TS EN 12127: 1999. Tekstil-Kumaşlar-Küçük Numuneler Kullanarak Birim Alan Başına Kütlenin Tayini.

20.TS 7128 EN ISO 5084: 1998. Tekstil-Tekstil ve Tekstil Mamullerinin Kalınlık Tayini.

21. ASTM D7984-16 Standard Test Method for Measurement of Thermal Effusivity of Fabrics Using a Modified Transient Plane Source (MTPS) Instrument.

22. Mangat, A.E., Hes, L., Bajzik, V., Mazari, A., 2018. Thermal Absorptivity Model of Knitted Rib Fabric and its Experimental Verification. Autex Research Journal, 18(1), 20-27. 